\title{
The Coastal Sandy Land for People Food Security (Case Study in Karangsewu Village, Galur Sub District, Kulonprogo District, Yogyakarta Special Region)
}

\author{
Rahma Hayati ${ }^{1}$ \\ \{rahmahayati72@mail.unnes.ac.id $\left.{ }^{1}\right\}$ \\ ${ }^{1}$ Geography Department, Social Science Faculty, UNNES, Indonesia
}

\begin{abstract}
The purpose of this study is to find out contribution of agricultural activities in coastal sandy land to the food security of people in the case village. This research is qualitative research which used spatial approach. Methods of data collect were literature studies, documents from relevant government agencies, observations, surveys and indepth interviews. The results of this study are; 1) coastal sandy land for farming in Karangsewu Village are able to supply food to other regions for vegetables, fruits, nuts, corn, cassava, and sweet potatoes; 2) food distribution outside and inside Karangsewu Village are smoothly; 3) people in Karangsewu village have good access to food because it is supported by good transportation facilities and infrastructure and high income; and 4) people in Karangsewu Village have many choices about foodstuffs, because they plant several types of food crops and are able to bring in various types of other foodstuffs.
\end{abstract}

Keywords: Coastal Sandy Land, Food Security, Food Crops

\section{Introduction}

Kulonprogo Regency has 10 (ten) villages directly adjacent to the Indian Ocean or they call coastal village. The area of coastal villages in Kulonprogo Regency is 5,643 hectares with 24 (twenty four) kilometers of coastline. The width of the sandy coastal from the lowest tide point is between 400 meters to 1800 meters landwards (Hayati, R, 2017). Geomorphologically, coastal sandy land in Kulonprogo Regency are sand dune, beach and beach-ridges (Santosa, L. W., 2010). The coastal sandy land area is 3,288 hectares (calculation of Google Map, January 20th, 2018), represent 58\% of the area of coastal village in Kulonprogro Regency.

Coastal sandy land is one type of the marginal land for agriculture (Siradz, S. A., 2007). Condition of marginal coastal sandy land for cultivation, generally can be resolved by farmers to get good crops (Hayati, R., 2017). The farmers in coastal sandy land at Kulonprogo Regency have implemented agricultural intensification and agricultural extension. Agricultural intensification is carried out with the five agriculture principles (Indonesia: panca usaha tani) to seven agriculture principles (Indonesia: sapta usaha tani). Agricultural extensification are carried out by farmers with overhauling sand dunes into agricultural land.

Agricultural products from coastal sandy land in Kulonprogo Regency are quite diverse. Abundant agricultural products from coastal sandy land have made four sub-districts in the coastal area of Kulonprogo Regency as a central producer for certain fruits and vegetables. The most cultivated fruits and vegetables are melon and watermelon, mustard, large chili and 
chili. In 2015 the four commodities had a large contribution to the production of similar fruits and vegetables in Kulonprogo Regency.The contribution from production of chili is $40.73 \%$, large chili $93.44 \%$, caisim mustard $100 \%$ and melon and watermelon $85.24 \%$ [1].

The potential of coastal sandy land in Kulonprogo Regency which is capable of producing food products in this case vegetables and fruits, is one of the great potentials to play a role in maintaining regional food security. Food security is a reflection of the food availability involve the sufficient, nutritious, and evenly distributed food that can be accessed by everyone. The absorption from that food can be carried out maximally for the achievement of healthy and productive life [2]. The concepts, definitions and policies regarding food security continue to develop. Until this decade there have been at least four important aspects to achieving food security [3], namely: availability of supply, food distribution, accessibility of the community to food and choice of various commodities by households.

Coastal sandy land in Kulonprogo Regency has been able to produce abundant food from year to year. In terms of food supply, coastal sandy land farmers have the ability to export foodstuff for other regions. Based on these matters, this study aims to determine the contribution of coastal sandy land agriculture activity to people food security in the case village.

\section{Literatur Review}

Coastal sandy land is a marginal land with low productivity, characterized by the dominant material (> 80\%) consisting of sand, so that the availability of water and nutrients is very low [4]-[6]. These conditions result only certain plants can grow or require technological inputs to improve their capabilities.

Geomorphologically, the coastal area in Kulonprogo Regency consists of 4 land units [7], namely are sand dune, beach, beach-ridges and fluviomarin plains. The sand dune and beachridges are good and potential aquifers, but there are localize like groundwater bags. This aquifer is a separate system from the fluviomarin plain to aquifer system. The study explained that in the sand dune aquifer system and the sandbank, there was a layer of sand containing ground water to a depth of approximately 40 meters. This layer guarantees the availability of ground water for agriculture in coastal sandy land in Kulonprogo Regency. The lower part of the land unit is limited by aquitard layers which are saturated by brackish ground water. This saturated layer is able to withstand the escape of shallow ground water above it.

The coastal sandy land farmers make wells in order to coverage the water needs of plants at the beginning of the massive activity of agriculture in coastal sandy land. [4] suggested that coastal sandy land can be developed well if the beneficial factors are utilized and added with input technology, especially biotechnology, so that it can become a productive land.

The high porosity in coastal sandy land and the presence of saturated clay layers also results in the accumulation of concentrations of Nitrates from artificial fertilizers used for plants. Studies in Sri Lanka show that high concentrations of Nitrates have spread to residential areas. Nitrates concentration has exceeded the standard of drinking water from $\mathrm{WHO}$, so that it is dangerous for people [8]. Must be careful action for developing agriculture activity in coastal sandy land, so that not disturb the environment quality, especially for settlements.

The agriculture activities on sand dunes in Turkey proved to be more profitable than in the lower plain [9]. Agricultural activities on sand dunes that are very beneficial have changed the 
shape of sand dunes a lot, so that it removes many sand dunes native bio-diversity in Turkey. Massive agricultural activities on sand dunes should be accompanied by regulations that can save sand dunes.

The coastal sandy land on the south coast of Yogyakarta has been cultivated intensively. The results of [10] showed that farmers in the south Yogyakarta coastal sandy land have applied a cropping system that was divided into 4 (four) planting seasons, namely October December, January - March, April - June, and July - September. The applied planting season shows a higher intensity compared to technical irrigated rice fields, that is three times a year. More planting seasons lead to higher productivity in coastal sand fields.

The coastal sandy land in Yogyakarta has been widely cultivated for agriculture. In the 1990s coastal sandy land in Bantul Regency was successfully used for palawija cultivation [11]. Coastal sandy land are also suitable to be developed sesame plants in Purworejo Regency [12]. Research by [1] in two coastal villages in Kulonprogo Regency shows that coastal sandy land are able to produce good crops (cassava, sweet potatoes, peanuts), vegetables (eggplant, bitter melon, chinese cabbage, chili, tomato) and fruit (watermelon, melon, dragon fruit). Agriculture products from coastal sandy land will be a source of food for the region and other regions. The use of technology in coastal sandy land has been widely carried out. Technology have been used to improve physical, chemical and soil organism properties for better soilwater-plant interactions. Another technology needed is technology that has attention to the interactions between plants and the atmosphere, because coastal land is very excessive for the availability of solar energy, wind and biomass energy [13].

The existence of marginal land in various regions in Indonesia leads to an idea whether coastal sandy land is able to support food security for people living in the area and other regions. Food security is a situation where everyone has physical and economic access to food so that they are healthy and productive [2]. The study of food security involves four indicators, namely availability, accessibility, utilization, and stability [14]. The Government of Indonesia through the Food Security Agency has carried out various activities to achieve national food security, namely Food Supply Availability and Handling Development activities, Food Price Distribution and Stability System Development activities, and Food Diversity and Safety Diversification Development [15].

\section{Research Method}

This research is qualitative research which used spatial approach. The location of this study is Karangsewu Village, Galur District, Kulonprogo Regency (Figure 1). The type of data in this study are primary data and secondary data. Primary data is obtained by observation, interviewing farmers or farmer group leaders by using interview protocols and indepth interview to obtain data on plant species, planting patterns, planting systems, and productivity. Secondary data in this study were literature studies, documents from relevant government agencies and non-government institutions. Primary data and secondary data are collected to obtain important information about food security indicators which include availability, accessibility, utilization, and stability. Data were analyzed by qualitative descriptive method, making a systematic, factual, and accurate description or description of the facts, characteristics and relationships of the phenomena investigated. 


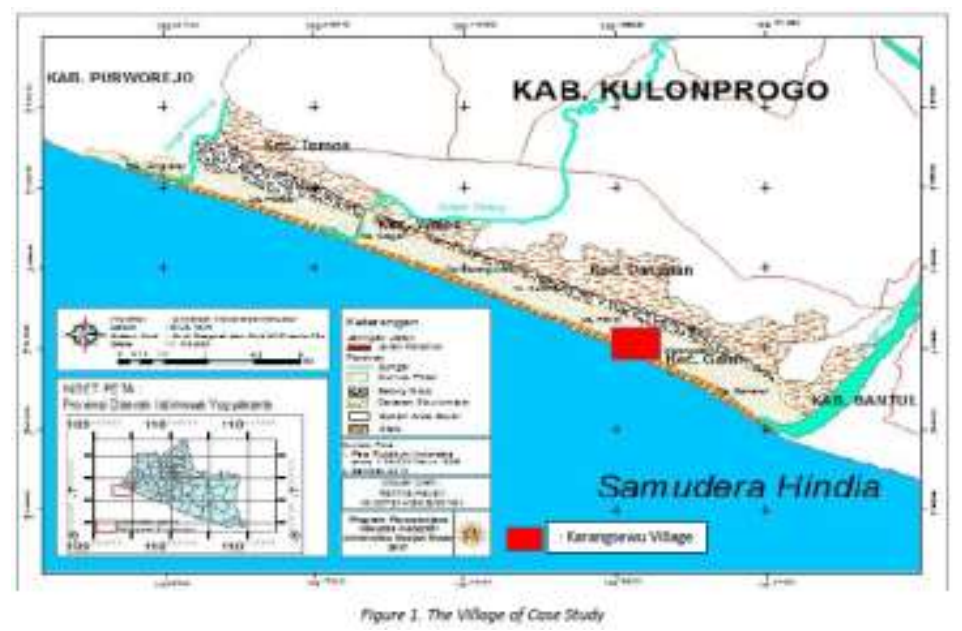

\section{Result and Discussion}

Karangsewu Village, Galur District, Kulonprogo Regency, is astronomically located between $7^{0} 56^{\prime} 27$ "- $7^{0} 58^{\prime} 06^{\prime \prime}$ South and $110^{\circ} 10^{\prime} 00$ "- 110 $10^{\circ} 13^{\prime} 00^{\prime \prime}$ East. The location of the settlement is approximately 1.5 kilometers north of the coast. The area of Karangsewu Village is $927 \mathrm{ha}$, consisting of 17 hamlets.

Geomorphologically based on the origin of the main process, the origin of landform in Karangsewu Village is marine process and aeolian process. The marine process landform can be grouped into two, namely the young beach unit in the south extending along the beach and the beach ridges in the north. Beach ridges have relatively flat topography, regular relief, and are dominated by sand material with finer size than the young beach unit, mixed with a little dust and clay at the top. This condition causes aquifers in this landform to be quite good, shallow groundwater and tasteless so that it is widely used by people as a source of clean water. Settlements and grounds are in this landform.

The landform of the wind process (aeolian) is a complex of sand dunes that intersect with swale. The whole complex of sand dune and swale forms a choppy relief composed of loose sand material. The accumulation of finer materials such as clay and dust is often found at the base of swale, which allows this land to be used as agricultural land. The agriculture activities of coastal sandy land in Karangsewu Village are widely in this landform, especially intensive agricultural activities.

The types of plants in the coastal sandy land of Karangsewu Village starting in the 1990s have changed from palawija to vegetable and fruit crops. Vegetable plants consist of chili, mustard caisim, eggplant, bitter melon, long beans and tomatoes. Chili is the most preferred vegetable crop of farmers in Karangsewu Village. Chili can be harvested at the age of three months with ten to fifteen times picking (10-15 times picking). The coastal sandy land farmers in Karangsewu Village plant chili one to two times a year, the other time is used to plant other fruits and vegetables. The next vegetable crop that many farmers cultivate is caisim mustard. Caisim mustard plants can be harvested at the age of thirty five days. The good combination of vegetables in a year has made Karangsewu Village a supplier of caisim mustard and chili to any regions and cities. 
Fruit plants cultivated by coastal sandy land farmers in Karangsewu Village are watermelons and melons. Watermelon and melon products from Karangsewu Village in 2017 were 247,129 tons and constituted $13 \%$ of similar production in Kulonprogo Regency. These commodities are almost entirely sold outside the village until they reach the Jakarta market. The other commodities found on coastal sandy land in Karangsewu village are nuts, corn, cassava, and sweet potatoes. These commodities have significant amount of production compared to chili, caisim mustard, melon and watermelon.

Physical accessibility with an indicator of the road network in Karangsewu Village, Galur District, shows good conditions. Karangsewu village which is directly adjacent to the Indian Ocean is located on the southern route of Yogyakarta. Karangsewu village is traversed by Daendeles Road for 4.5 kilometers. Daendels Road is a national road with good quality. This route is an alternative route to cities in the southern part of Java Island and towards Bandung and Jakarta. The main road in Karangsewu Village is asphalt with good quality. Entering the hamlets in Karangsewu Village are all connected to the village road with quality cement cast. The cement cast road in residential areas and between settlements is partly built with the village budget and partly with community self-help. Karangsewu villagers have built cement cast quality roads as the main road from settlements to fields to support agricultural activities in the coastal sandy land. Residents have also built cast-quality roads that connect inter-field blocks. The existence good quality roads so that in the field complex is very helpful for farmers in transporting input material for agricultural activities, harvesting and post-harvest activities. The accessibility of the population to sell agricultural products outside the area is very smooth. Accessibility for input requirements for agricultural activities and the need to supply food to Karangsewu Village is also very easy, due to the availability of good road networks.

Interviews with farmers and village leaders show that agricultural activities in coastal sandy land have increased the economic capacity of the people. Farmers' income with a minimum of $500 \mathrm{~m} 2$ of sandy land with a combination of vegetables and fruits that are able to produce an average income above Rp. 3,000,000 per month. This income above from the minimum fee for regional labour in Kulonprogo Regency. The economic capacity of the population of Karangsewu Village makes the population have good access to food. Food that is not produced from this village is easily imported from outside the area, because physical access by the road networks is well available. Karangsewu Village people have no difficulty getting quality food for nutritional needs.

\section{Conclusion}

Marginal land, in this case coastal sandy land in Karangsewu Village, Galur District, Kulonprogo Regency can be used as an area source of food. High agricultural productivity in coastal sandy land makes the population in this village have high food security, both seen from indicators of supply, distribution, accessibility and capability.

\section{References}

[1] R. HAYATI, "KERENTANAN DAN STRATEGI PENGHIDUPAN KOMUNITAS PETANI LAHAN PASIR PANTAI (Studi Kasus di Dusun Gupit IV, Desa Karangsewu, Kecamatan Galur dan Dusun Ngentak, Desa Jangkaran, Kecamatan Temon, Kabupaten Kulonprogo).” Universitas Gadjah Mada, 2017. 
[2] T. Dirhamsyah, J. H. Mulyo, D. H. Darwanto, and S. Hartono, Ketahanan pangan: kemandirian pangan dan kesejahteraan masyarakat daerah rawan pangan di Jawa. Plantaxia, 2016.

[3] F. Kasryno, "Kebijakan Pembangunan Pertanian Dalam Era dalam Era Globalisasi dan Otonomi: Ketahanan Pangan dan Penanggulangan Kemiskinan," Widyakarya Nas. Pangan dan Gizi VIII, 2004.

[4] S. A. Siradz and S. Kabirun, "Pengembangan lahan marginal pesisir pantai dengan bioteknologi masukan rendah," J. Ilmu Tanah dan Lingkungan. Jur. Tanah, Fak. Pertan. UGM, vol. 7, pp. 83-92, 2007.

[5] T. T. Liu, B. G. McConkey, Z. Y. Ma, Z. G. Liu, X. Li, and L. L. Cheng, "Strengths, weaknessness, opportunities and threats analysis of bioenergy production on marginal land," Energy Procedia, vol. 5, pp. 2378-2386, 2011.

[6] D. Jiang, M. Hao, J. Fu, D. Zhuang, and Y. Huang, "Spatial-temporal variation of marginal land suitable for energy plants from 1990 to 2010 in China," Sci. Rep., vol. 4, p. 5816, 2014.

[7] L. W. Santosa, "Pengaruh genesis bentuklahan terhadap hidrostratigrafi akuifer dan hidrogeokimia dalam evaluasi airtanah bebas: kasus pada bentanglahan kepesisiran Kab. Kulonprogo DIY," text, 2010.

[8] P. Jayasingha, A. Pitawala, and H. A. Dharmagunawardhane, "Vulnerability of coastal aquifers due to nutrient pollution from agriculture: Kalpitiya, Sri Lanka," Water, Air, Soil Pollut., vol. 219, no. 1-4, pp. 563-577, 2011.

[9] K. T. Yılmaz, D. Harmanc1, Y. Ünlükaplan, H. Alphan, and L. Tezcan, "Impacts of Agriculture on Coastal Dunes and a Proposal for Adaptation to Climate Change: The Case of the Akyatan Area in the Seyhan Delta," in Climate Change Impacts on Basin Agro-ecosystems, Springer, 2019, pp. 165-182.

[10] A. N. SETIAWAN, B. H. ISNAWAN, and L. I. S. N. AINI, "Sistem Pengelolaan Lahan Pasir Pantai untuk Pengembangan Pertanian," 2015.

[11] B. Basuki, "Peran serta masyarakat petani lahan pesisir Kabupaten Bantul dalam kegiatan pertanian di area pelestarian hutan konservasi pantai.," 2008.

[12] M. Barus, "PENGARUH TAKARAN PUPUK KANDANG TERHADAP PERTUMBUHAN DAN HASIL WIJEN (Sesamum indicum. L.) DI LAHAN PASIR PANTAI." Universitas Gadjah Mada, 2013.

[13] S. Gunadi, "Teknologi pemanfaatan lahan marginal kawasan pesisir," J. Teknol. Lingkung., vol. 3, no. 3, 2011.

[14] FOA, "Basic Concepts of Food Insecurity."

[15] B. K. Pangan and K. PERTANIAN, ") Pedoman Pelaksanaan Program Kerja dan Anggaran Badan Ketahanan Pangan Tahun 2017," Jakarta: Badan Ketahanan Pangan, 2017. 